\title{
Polar bivalves are characterized by high antioxidant defences
}

\author{
Lionel Camus, Bjørn Gulliksen, Michael H. \\ Depledge \& Malcolm B. Jones
}

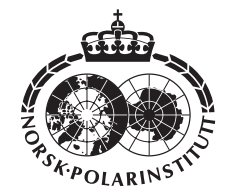

Inevitably, aerobic life leads to the formation of deleterious reactive oxygen species (ROS) which participate in biomolecule oxidation, hence augmenting biomolecule turnover. Organisms have adapted to counteract the noxious effects of ROS by developing a battery of antioxidant defences (AOX) which comprise enzymes and low-molecular weight scavengers. Past studies have reported elevated AOX levels in polar pectinid bivalves compared with temperate congeners. This finding is controversial as mitochondrial ROS generation is low in polar versus temperate species, and, to date, there is no generally accepted explanation of the causes of increased basal AOX levels in polar waters. We suggest that the low food availability in those ecosystems may result in polar marine ectotherms diverting some energy into the maintenance of high AOX. We tested this hypothesis by comparing the total oxyradical scavenging capacity (peroxyl, hydroxyl and peroxynitrite) of three clam species: Laternula elliptica (Antarctic), Mya truncata (Arctic) and Mya arenaria (temperate). The data confirmed that polar bivalves are characterized by higher AOX. Herein, we propose that high $\mathrm{AOX}$ is required in environments characterized by low food availability as AOX efficiently protects biomolecules, notably the RNA expressed at high levels by cold-water ectotherms. Also, high AOX may explain the relatively long lifespan of most polar ectotherms.

L. Camus, Akvaplan-niva, Polar Environmental Centre, NO-9296Tromsø,Norway,lc@akvaplan.niva.no; B. Gulliksen, The University Centre in Svalbard, Box 156, NO-9170 Longyearbyen, Norway; M. H. Depledge $\&$ M. B. Jones, School of Biological Sciences, University of Plymouth, Plymouth, Devon, PL4 8AA, UK.

\begin{abstract}
A direct consequence of aerobic life is the production of deleterious reactive oxygen species (ROS) generated by the reduction of molecular oxygen to water by the addition of four electrons (see DiGiulio et al. 1989). To counteract the toxicity of ROS, organisms have developed antioxidant defences which comprise various low-molecular weight, free radical scavengers, such as glutathione, beta-carotene and vitamins $\mathrm{A}, \mathrm{E}$ and $\mathrm{C}$, and a number of specific enzymes including superoxide dismutase (SOD) which reduces $\mathrm{O}_{2}{ }^{-}$into $\mathrm{H}_{2} \mathrm{O}_{2}$, catalase which reduces $\mathrm{H}_{2} \mathrm{O}_{2}$ produced by $\mathrm{SOD}$ to produce water and oxygen, and glutathione peroxidase which reduces peroxides $\left(\mathrm{H}_{2} \mathrm{O}_{2}\right.$
\end{abstract}

or hydroperoxides) by oxidizing two molecules of glutathione. Oxidative stress will arise when antioxidant defences (AOX) are overwhelmed by cellular production of ROS (Sies 1985), resulting in oxidative tissue damages which imply lipid peroxidation, DNA damage, protein degradation, metabolic malfunctions and cell death (Winston \& DiGiulio 1991).

While the understanding of oxidative stress processes in temperate marine organisms has expanded dramatically in the last 20 years or so, more recently, there has been a growing interest in examining the prooxidant and antioxidant processes in animals inhabiting permanently cold 
marine environments such as polar oceans (Regoli et al. 1997, Viarengo et al. 1998, Regoli, Nigro, Bompadre et al. 2000, Regoli, Nigro, Chiantore et al. 2000, Estevez et al. 2002, Heise et al. 2003). Cold stenothermal bivalves are characterized by a low metabolic rate (Clarke 2003) and a minimized mitochondrial respiration level, which guarantee low mitochondrial ROS output at habitat temperature (Heise et al. 2003). Nonetheless, in spite of an expected low level of internal oxidative pressure, AOX of polar bivalves is higher than that of temperate species (Regoli et al. 1997, Regoli, Nigro, Bompadre et al. 2000, Estevez et al. 2002, Heise et al. 2003); similar findings were reported for polar fish (Gieseg et al. 2000, Dunlap et al. 2002). To date, there have been no clear explanations of the causes and benefit of this puzzling finding. As the success of polar ectotherms relies on their ability to deal with low and stable temperature and high seasonality in food supply (with low food availability for about 10 months) (Clarke 2003), it appears logical to contemplate how it could benefit polar marine ectotherms to divert some energy into the maintenance of high basal AOX. Numerous studies comparing the oxidative processes of the Antarctic clam Laternula elliptica and the temperate clam Mya arenaria have been published (Abele et al. 2002, Estevez et al. 2002, Heise et al. 2003). Therefore, in this study, the total oxyradical scavenging capacity assay (TOSC) has been measured in Laternula elliptica (Antarctica), Mya truncata (Arctic) and Mya arenaria (temperate) to compare their different resistance to oxidative stress to elucidate the causes and the consequences of the elevated $\mathrm{AOX}$ in polar bivalves.

\section{Materials and Methods}

\section{Animal sampling}

Mya truncata was hand sampled by SCUBA divers near the Norwegian settlement of Longyearbyen at the outer part of Adventfjorden (Isfjorden, Svalbard, $78^{\circ} 13^{\prime} \mathrm{N}, 15^{\circ} 39^{\prime} \mathrm{E}$ ). Sampling was performed during the first week of September 2003. The digestive glands (hepatopancreas) of five individuals (4.54 $\mathrm{cm}$ average shell length) were dissected and frozen in liquid nitrogen for TOSC measurement. The surface seawater temperature was $5.5^{\circ} \mathrm{C}$ at the time of sampling and the phytoplankton bloom was completed (Weslawski et al. 1988).
Mya arenaria was hand sampled at low tide at the end of the main feeding season in November 2003 from the Yealm Estuary, Devon, United Kingdom $\left(50^{\circ} 05^{\prime} \mathrm{N}, 4^{\circ} 50^{\prime} \mathrm{W}\right)$. The bivalves were packed in humid and water-ice cooled boxes, airfreighted to Norway and stored at $10^{\circ} \mathrm{C}$ in running seawater for one week and fed the two first days with Isochrysis $s p$. before analysis. Hepatopancreatic tissue from five individuals $(7.36 \mathrm{~cm}$ average shell length) was frozen in liquid nitrogen for TOSC analysis.

Laternula elliptica, widely distributed in nearshore waters around the Antarctic continent in relatively high biomass, was hand sampled by SCUBA divers in the last week of January 2000 (Austral summer) at McMurdo, Ross Island, Antarctica $\left(166^{\circ} 30^{\prime} \mathrm{E}, 77^{\circ} 45^{\prime} \mathrm{S}\right)$. According to ElSayed (1984), the phytoplankton stock achieves a maximum at the beginning of January and decreases by the end of the month; therefore, L. elliptica was actively feeding at the time of collection. Animals were stored in running seawater at $-1.5^{\circ} \mathrm{C}$ for two days before the hepatopancreas was dissected out from five individuals (ca. $7 \mathrm{~cm}$ in shell length). The gland was frozen in liquid nitrogen and airfreighted to Norway in liquid nitrogen.

\section{TOSC assay}

The method was based on Winston et al. (1998) and Regoli \& Winston (1999), except that buffers were adjusted for marine invertebrates. Digestive glands were homogenized with a Potter-Elvehjem glass/Teflon homogenizer in four volumes of $100 \mathrm{mM} \mathrm{KH}_{2} \mathrm{PO}_{4}$ buffer, $2.5 \% \mathrm{NaCl}$, pH 7.5. The homogenate was centrifuged at $100000 \times \mathrm{g}$ for $1 \mathrm{~h}$, and cytosolic fractions were aliquoted and stored at $-80^{\circ} \mathrm{C}$. Microconcentrator devices, with membrane cut-off of $3 \mathrm{kDa}$ (Microcon ${ }^{\circledR}$, Millipore Corporation, Bedford, MA, USA), were used to separate the soluble antioxidants from proteins in the cytosolic fraction as performed by Winston et al. (1998). TOSC was measured in the cytosolic and soluble fractions as follows. Peroxyl radicals are generated by the thermal homolysis of 2-2'-azo-bis-(2 methyl-propionamidine)-dihydrochloride (ABAP) at $35^{\circ} \mathrm{C}$. The iron-ascorbate Fenton reaction was used for hydroxyl radicals, whereas peroxynitrite was generated from 3-morpholinosydnomine (SIN-1), a molecule that concomitantly releases nitric oxide and superoxide anion, which rapidly combine to form HOONO. Final assay conditions were: (a) $0.2 \mathrm{mM} \alpha$-keto- 
$\gamma$-methiolbutyric acid (KMBA), $20 \mathrm{mM}$ ABAP in $100 \mathrm{mM}$ potassium phosphate buffer, $\mathrm{pH} 7.4$ for peroxyl radicals; (b) $1.8 \mu \mathrm{M} \mathrm{Fe}^{3+}, 3.6 \mu \mathrm{M}$ EDTA, $0.2 \mathrm{mM} \mathrm{KMBA}, 180 \mu \mathrm{M}$ ascorbic acid in $100 \mathrm{mM}$ potassium phosphate buffer, $\mathrm{pH} 7.4$ for hydroxyl radicals; and (c) $0.2 \mathrm{mM} \mathrm{KMBA}$ and $80 \mu \mathrm{M}$ SIN1 in $100 \mathrm{mM}$ potassium phosphate buffer, $\mathrm{pH} 7.4$ with $0.1 \mathrm{mM}$ diethylenetriaminepentaacetic acid (DTPA) for peroxynitrite. Peroxyl, hydroxyl and peroxynitrite radicals can oxidize the substrate KMBA to ethylene gas which is measured with gas chromatography. With these assay conditions, the various oxyradicals induce a comparable yield of ethylene in the control reaction; thus the relative efficiency of cellular antioxidants is compared by their ability to counteract a quantitatively similar prooxidant challenge (in terms of KMBA oxidation). Reactions were carried out in $10 \mathrm{ml}$ rubber septa-sealed vials in a final volume of $1 \mathrm{ml}$. Ethylene production was measured by gas-chromatographic analysis of $200 \mu 1$ taken from the head space of the reaction vials. Ethylene formation was monitored for 96 min with a Hewlett Packard (HP 5890 series II) gas chromatograph equipped with a Supelco SPB-1 capillary column $(30 \mathrm{~m} \times 0.32 \mathrm{~mm} \times 0.25 \mu \mathrm{m})$ and a flame ionization detector (FID). The oven, injection and FID temperatures were 35,160 and $220^{\circ} \mathrm{C}$, respectively; helium was the carrier gas (flow rate $1 \mathrm{ml} / \mathrm{min}$ ) and a split ratio 20:1 was used. The data acquisition system was run by the software Millenium $32^{\circledR}$ (Waters). Each analysis required the measurement of control (no antioxidant in the reaction vial) and sample reactions (biological fluid in the vial). In the presence of antioxidant, ethylene production from KMBA was reduced quantitatively and higher antioxidant concentrations resulted in longer periods in which ethylene formation was inhibited relative to controls. By plotting the absolute value of the difference between the ethylene peak area obtained at each time point for the sample and control reaction it is possible to visualize whether the oxyradical scavenging capacity of the solution is changed. The area under the kinetic curve was calculated mathematically from the integral of the equation that best defines the experimental points for both the control and sample reactions. TOSC is then quantified according to the equation:

$$
\mathrm{TOSC}=100-(\operatorname{IntSA} / \operatorname{IntCA} * 100)
$$

where IntSA and IntCA are the integrated areas from the curve defining the sample and control reactions, respectively.

Thus, a sample that displays no oxyradical scavenging capacity would give an area equal to the control (IntSA/IntCA =1) and a resulting $\mathrm{TOSC}=0$. On the other hand, as IntSA/IntCA goes to 0 the hypothetical TOSC value approaches 100. Because the area obtained with the sample is related to that of the control, the obtained TOSC values are not affected by small variations in instrument sensitivity, reagents or other assay conditions. The specific TOSC value was calculated by dividing the experimental TOSC by the concentration of protein (Bradford 1976) used for the assay.

\section{Data treatment}

Statistical analyses were made using JMP v3.2.6., SAS Institute, Inc., Cary, NC, USA. The TukeyKramer test was used to test whether group means between bivalve species were significantly different.

\section{Results}

\section{TOSC profiles of the three species}

The Antarctic clam, Laternula elliptica, was characterized by a high TOSC value for peroxyl and low values for hydroxyl and peroxynitrite (Fig. 1). The TOSC for peroxyl was twice that for hydroxyl and peroxynitrite, indicating elevated resistance of $L$. elliptica toward peroxyl radicals. The soluble fraction accounted for a relatively low proportion of the total TOSC values: 25,50 and $50 \%$ for peroxyl, hydroxyl and peroxynitrite, respectively (Fig. 2). The latter indicated that peroxyl radicals were scavenged mainly by enzymes in the Antarctic species.

Mya truncata, the Arctic clam, was characterized by high, intermediate and low TOSC values for peroxyl, hydroxyl and peroxynitrite, respectively. The contribution of the soluble fraction to the TOSC value reached 87, 29 and $49 \%$ for peroxyl, hydroxyl and peroxynitrite. This indicated that soluble antioxidants (e.g. glutathione) were mainly responsible for scavenging peroxyl in $M$. truncata while enzymes (e.g. catalase) appeared to prevent the formation of hydroxyl radicals by removing $\mathrm{H}_{2} \mathrm{O}_{2}$ (Regoli, Nigro, Bompadre et al. 2000). 


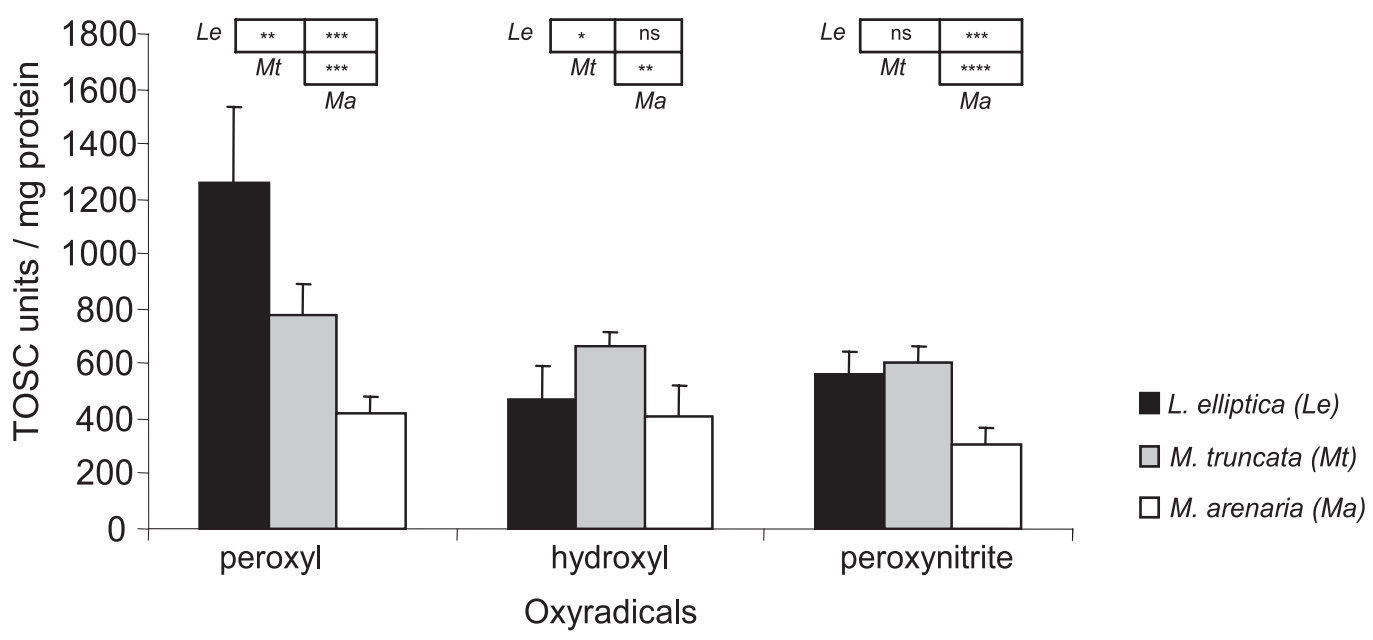

Fig. 1. Cytosolic total oxyradical scavenging capacity (expressed as TOSC units per mg protein) for peroxyl, hydroxyl and peroxynitrite measured in the digestive gland of Laternula elliptica, Mya truncata and Mya arenaria (mean values \pm standard deviation, $n=5$ ). Asterisks indicate significant difference (ns=non significant, $*=P<0.05, * *=P<0.01, * * *=P<0.001, * * * *=P<0.0001$ ) in TOSC values within the considered ROS between bivalve species.

The temperate clam, Mya arenaria, was characterized by high, intermediate and low TOSC values for peroxyl, hydroxyl and peroxynitrite, respectively. Soluble antioxidant accounted for ca. $50 \%$ of the total TOSC values for each radical.

\section{Interspecific TOSC comparison}

TOSC values for peroxyl, were high, intermediate and low for L. elliptica, M. truncata and $M$. arenaria, respectively, indicating a higher capacity to deal with peroxyl radicals in polar bivalves (Fig. 1); TOSC values were significantly distinct between species $(P<0.01)$. The TOSC value in L. elliptica was three times that of the temperate species. However, the TOSC value for the hydroxyl radical in the Arctic species was significantly higher than in L. elliptica $(P<0.05)$ and $M$. arenaria $(P<0.01)$; the two latter species were not significantly different $(P>0.05)$. Finally, the polar species shared similar TOSC values for peroxynitrite and these were significantly higher $(P<0.001)$ than those of the temperate species $M$. arenaria. The latter may be explained by a higher contribution of enzyme since the contribution of the soluble, low-molecular weight scavengers was similar in the three clams.

\section{Discussion}

A clear interspecific difference in TOSC values indicated greater capability of polar than temperate bivalve species to counteract peroxyl radicals, with a high, intermediate and low TOSC value for the Antarctic, Arctic and temperate species, respectively. These data corroborate earlier comparative studies of TOSC in scallop species (Regoli, Nigro, Bompadre et al. 2000). The great discrepancy in the contribution of the soluble fraction to the TOSC of peroxyl between $L$. elliptica (near 30\%) and $M$. arenaria (near 90\%) is in agreement with the activity of glutathione S-transferases (GST) in polar scallops, with high values for the Antarctic species compared with the Arctic species. Differences in diets (quality/ quantity) may explain these differences. Moreover, L. elliptica was sampled during the peak of the feeding season while the two others were not, supporting the hypothesis that GST activity was probably high in the Antarctic clam to deal with peroxyl radicals generated during feeding processes. The Arctic clam was characterized by a high TOSC value for hydroxyl whereas the Antarctic species had a TOSC value similar to that of the temperate species. These findings conflict with those of Regoli, Nigro, Bompadre et al. (2000) who reported higher TOSC for hydroxyl radicals in Antarctic compared to temperate scal- 


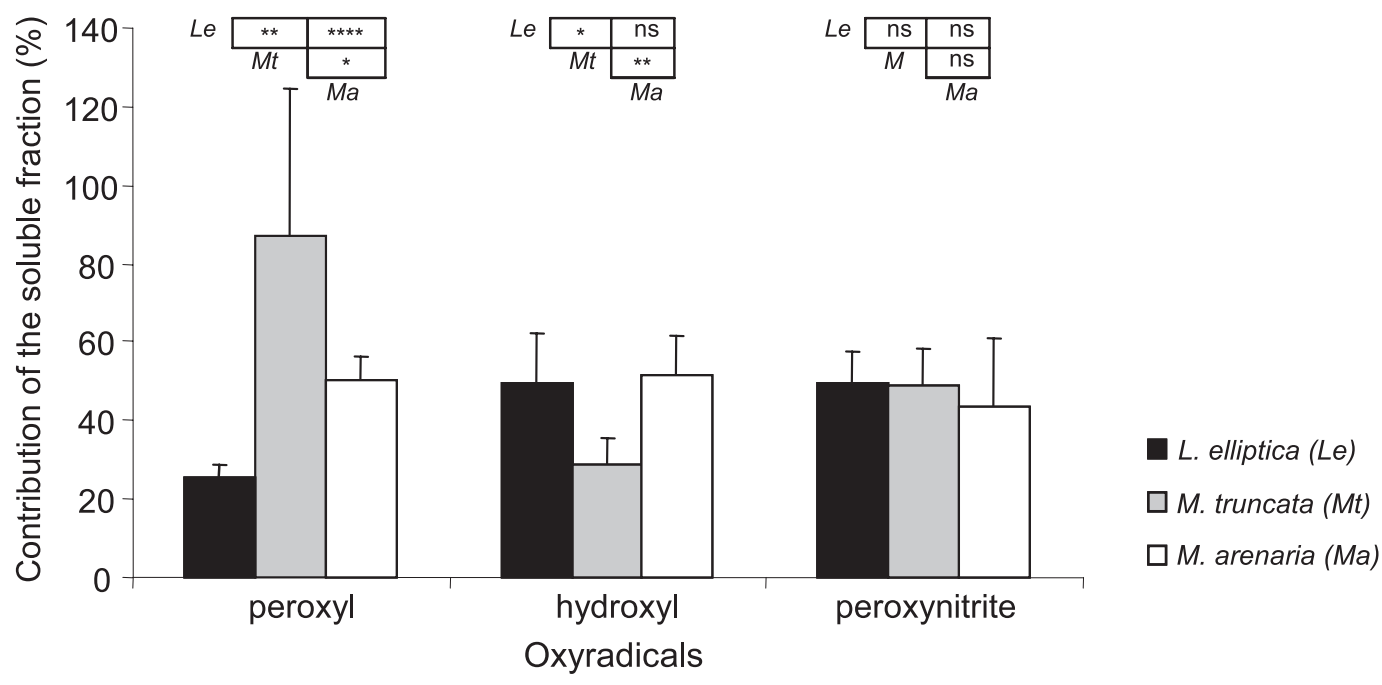

Fig. 2. Percentage contribution of the soluble fraction of the TOSC values for peroxyl, hydroxyl and peroxynitrite measured in the cytosol of the digestive gland of Laternula elliptica, Mya truncata and Mya arenaria (mean values \pm standard deviation, $n=5$ ). The asterisks indicate significant difference (ns = non significant, $*=P<0.05, * *=P<0.01, * * *=P<0.001, * * * *=P<0.0001)$ in TOSC values within the considered ROS between bivalve species.

lops. As TOSC values for hydroxyl are related to catalase activity (Regoli \& Winston 1999), our findings are in disagreement also with Estevez et al. (2002) who reported a catalase activity (measured in the digestive gland) four times higher in $L$. elliptica than in $M$. arenaria. Both polar species had higher resistance toward peroxynitrite radicals than the temperate species; this could indicate a higher activity of the SOD enzyme since the contribution to the TOSC value of the soluble, low-molecular weight scavengers was similar between the three clams. Moreover, SOD was demonstrated to scavenge the superoxide anion generated by SIN-1 during the peroxynitrite production (Regoli \& Winston 1999).

Taken as an integrative index of resistance to oxidative stress, the TOSC assay demonstrated that the cytosolic fraction of the digestive gland of polar clams possesses a higher basal capability to deal with ROS than the corresponding fraction from temperate species as reported for scallops (Regoli, Nigro, Bompadre et al. 2000). An extensive review of prooxidant forces and antioxidant defences in cold-water ectotherms by Viarengo et al. (1998) revealed no clear pattern for enhanced oxidative challenge due to low temperature. The present study confirmed evidence of higher AOX levels in polar species, allowing further discussion of the causes of an elevated AOX level and the consequences for organisms inhabiting polar oceans.

It has been postulated that elevated AOX in polar bivalves could be related to the ROS, ubiquitous in sunlit natural waters, which are formed from the photoreactions of dissolved organic carbon (DOC) and oxygen in seawater. Indeed, the concomitant numerous polynyas, release of large amount of dissolved organic carbon from the melting ice, the ozone depletion at the poles (Schulz et al. 2001) that enhances UV radiation atmosphere penetration (Stolarski et al. 1992) and the $24 \mathrm{~h}$ illumination generate the production of $\mathrm{H}_{2} \mathrm{O}_{2}$ at levels comparable to lower latitudes (see Viarengo et al. 1998 for review). Moreover, direct exposure to UV-B generates internal oxidative stress. However, the bivalves investigated to date (clams and pectinids) are benthic organisms generally present at depths from 35 to $70 \mathrm{~m}$ where the level of ROS of biological concern is relatively low (Janssens et al. 2000).

Development of antioxidant defences relies primarily on internal ROS production which is associated with the metabolism of the organism (DiGiulio 1989, Winston \& DiGiulio 1991), notably the mitochondrial processes. Comparison of the ROS generation by isolated mitochondria in L. elliptica and $M$. arenaria revealed that, at the respective habitat temperatures $\left(1^{\circ} \mathrm{C}\right.$ for $L$. ellip- 
tica and $5-12^{\circ} \mathrm{C}$ for $M$. arenaria), basal rates of ROS formation were significantly higher in $M$. arenaria only above $10^{\circ} \mathrm{C}$ (Heise et al. 2003). If low metabolic rate at cold Antarctic temperatures keeps absolute rates of mitochondrial ROS production low and controls oxidative stress at habitat temperature, the measured elevated TOSC level in the polar species cannot be related to the natural internal ROS production.

Higher density of mitochondria was demonstrated in Antarctic compared to temperate fish (Johnston et al. 1998), suggesting the need for high AOX; however, mitochondrial density has not been reported for polar bivalves.

Levels of polyunsaturated fatty acids were shown to be relatively low in Mya truncata (Gillis \& Ballantyne 1999), Laternula elliptica (Ahn et al. 2000) and Adamussium colbecki (Viarengo et al. 1994), compared to temperate zone molluscs. Although the basal level of lipid peroxidation products was higher in an Antarctic pectinid, the same species showed an identical resistance to in vitro-stimulated lipid peroxidation as Pecten jacobaeus, a Mediterranean scallop, suggesting that the low unsaturated fatty acid content is a protective mechanism against attack of ROS (Viarengo et al. 1995, 1998). Interestingly, comparison of the lipid radical generation in L. elliptica and $M$. arenaria revealed higher levels in the Antarctic bivalve than in the temperate mud clam, even within the range of its habitat temperature (Estevez et al. 2002).

A particular feature of polar marine invertebrates is their physiological adaptation to the low food supply of the polar marine environment (Clarke 1991, 1993, 2003). This has profound consequences for the energy available to sustain all types of biological processes in the low and stable temperature of the polar oceans. One major component of basal processes which is energetically expensive (regardless of temperature) is protein synthesis (Hawkins 1991). In the context of cold-water adaptation, increased RNA concentration, relative to protein content, seems to be a general phenomenon in polar ectotherms (Marsh et al. 2001, Fraser et al. 2002) particularly polar bivalves (e.g. Adamussium colbecki) (Storch et al. 2003). This increased RNA content in cold water species may be the result of low protein turnover rates, with the advantage of enhanced cost-efficiency since the stoichiometric cost of protein synthesis is similar between temperate and Antarctic pectinid species (Storch \& Pörtner 2003). Pro- tein turnover is the outcome of a complex interaction between temperature, molecular stability and physiological function, notably the efficiency of AOX preventing proteins from oxidation. Hofmann \& Somero (1995) provided strong evidence for protein damage in mussels at their normal living temperature. However, as Clarke (2003) stated, as yet we do not know to what extent, if any, this varies between polar, temperate and tropical organisms. Nevertheless, it may be hypothesized that by having an extremely low RNA and protein turnover rate, polar marine invertebrates increase drastically the risk of exposing their RNA and proteins to oxidative stress. Damage due to oxidative stress can have deleterious consequences on the fitness of polar marine invertebrates, and low food availability may limit the repair and replacement of damaged biomolecules as shown in Antarctic scallops (Storch et al. 2003) and limpets (Fraser et al. 2002). The high AOX, measured in this study, and supported by others in polar marine bivalves (Regoli, Nigro, Bompadre et al. 2000, Estevez et al. 2002), indicates that these organisms require a very efficient protection against oxidative stress to protect their biomolecules, notably the RNA pool. Elevated total oxyradical scavenging capacity would allow polar marine invertebrates to have a low RNA turnover rate and to live with a low food supply. Therefore, this high TOSC would not necessarily reflect the high prooxidant pressure of the environment but, rather, the essential need to protect the biomolecule pool from oxidative damage.

Evidence of reduced oxidative damage in a polar marine invertebrate was reported by Bluhm et al. (2001) who showed that the average yearly accumulation of lipofuscin, a pigment produced by the oxidation of macromolecules, in the tissue of the Antarctic shrimp Notocrangon antarcticus was considerably lower than rates published for species from lower latitudes. A putative link between biomolecule turnover rates and AOX level would imply an energy trade off between repair mechanisms and/or biomolecule production processes and antioxidant defences. This possibility remains to be demonstrated, notably by investigating the complex relationship existing between mitochondrial ROS production, AOX level, protein oxidation (i.e. measurement of carbonyl modifications), oxidation of the bases of mitochondrial and nuclear DNA (i.e. measurements of 8-hydroxy-2'-deoxyguanosine), degree of unsaturation of lipid and the impact of caloric restriction. 
Polar marine bivalves show a tendency for increased longevity compared with congeners from lower latitudes but the cause has never been elucidated fully. For example, Laternula elliptica can live for more than 20 years (Urban \& Mercuri 1998), Yoldia eightsi up to 60 years (Nolan \& Clarke 1993) and some high-latitude bivalves may reach 120 years (Peck \& Bullough 1993). For Mya truncata, age measurements suggest a lifespan of up to 50 years (personal observation). Ageing, a progressive and irreversible physiological decline, was shown to be caused mainly by the damaging effect of ROS, naturally produced during respiration (Sohal et al. 2002). The rate of ROS production is correlated directly with metabolic rate and inversely related to the maximum life span of the species under study ( $\mathrm{Ku}$ et al. 1993). The low food supply reduces metabolic activity, and therefore ROS production, and extends life span (Koizumi et al. 1992). Overexpressed antioxidant defences were shown to increase life span (Orr \& Sohal 1994). From the foregoing account, it may be hypothesized that elevated AOX, combined with low food supply and low metabolic rate experienced by polar bivalves, might explain the longevity of polar bivalves.

Acknowledgements.-We are grateful to the crew of the research vessel RV Jan Mayen, University of Tromsø. We thank Dr. Stacy Kim and Prof. Adam Marsh (Delaware University) for assisting with sampling Laternula elliptica in McMurdo Sound, Ms Alex Fraser (University of Plymouth) for sampling Mya arenaria. At the time when this research was carried out, L.C. was affiliated with The University Centre in Svalbard, Box 156, NO-9170 Longyearbyen, and Akvamiljø as, Mekjarvik 12, NO-4070 Randaberg, Norway. This study was financed by a Marie Curie grant through the European programme Training and Mobility of Researchers (contract ERBFMBICT983185), the Norwegian Research Council under the programme Marine Resource, Environment and Management (project 146478/120) and the Antarctic Biology Training Course"held at McMurdo in January 2000, sponsored by the National Science Foundation of the United States (D. T. Manahan PI) and the Norwegian marine research laboratory RF-Akvamiljø.

\section{References}

Abele, D., Heise, K., Pörtner, H. O. \& Puntarulo, S. 2002: Temperature dependence of mitochondrial function and production of reactive oxygen species in the intertidal mud clam Mya arenaria. J. Exp. Biol. 205, 1831-1841.

Ahn, I.-Y., Cho, K. W., Choi, K.-S., Seo, Y. \& Shin J. 2000:
Lipid content and composition of the Antarctic lamellibranch, Laternula elliptica (King and Broderip) (Anomalodesmata: Laternulidae), in King George Island during an austral summer. Polar Biol. 23, 24-33.

Bluhm, B. A., Thomas, B., Klages, M. \& Arntz, W. E. 2001: Occurrence of the autofluorescent pigment, lipofuscin, in polar crustaceans and its potential as an age marker. Polar Biol. 24, 642-649.

Bradford, M. M. 1976: A rapid and sensitive method for the quantitation of microgram quantities of protein utilizing the principle of protein-dye binding. Anal. Biochem. 72, 248-254.

Clarke, A. 1991: What is cold adaptation and how should we measure it? Am. Zool. 31, 81-92.

Clarke, A. 1993: Seasonal acclimatization and latitudinal compensation in metabolism: do they exist? Funct. Ecol. 7, 139-149.

Clarke, A. 2003: Costs and consequences of evolutionary temperature adaptation. Trends Ecol. Evol. 18(1), 573-581. DiGiulio, R. T., Washburn, P. C., Wenning, R. J., Winston, G. W. \& Jewell, C. S. 1989: Biochemical responses in aquatic animals: a review of determinants of oxidative stress. Environ. Toxicol. Chem. 8, 1103-1123.

Dunlap, W. C., Fujisawa, A., Yamamoto, Y., Moylan, T. J. \& Sidell, B. D. 2002: Notothenioid fish, krill and phytoplankton from Antarctica contain a vitamin E constituent $(\alpha$-tocomonoenol) functionally associated with cold-water adaptation. Comp. Biochem. Physiol. B, Biochem. Mol. Biol. 133, 299-305.

El-Sayed, S. Z. 1984: Productivity of Antarctic waters-a reappraisal. In O. Holm-Hansen et al. (eds.): Marine phytoplankton and productivity. Lecture notes on coastal and estuarine studies. Vol. 8. Pp. 19-34. Berlin: Springer.

Estevez, M. S., Abele, D. \& Puntarulo, S. 2002: Lipid radical generation in polar (Laternula elliptica) and temperate (Mya arenaria) bivalves. Comp. Biochem. Physiol. B, Biochem. Mol. Biol. 132, 729-737.

Fraser, K. P., Clarke, A. \& Peck, L. S. 2002: Low-temperature protein metabolism: seasonal changes in protein synthesis and RNA dynamics in the Antarctic limpet Nacella concinna Strebel (1908). J. Exp. Biol. 205, 3077-3086.

Gieseg, S. P., Cuddihy, S. Jonathan, V. H. \& Davison, W. 2000: A comparison of plasma vitamin $\mathrm{C}$ and $\mathrm{E}$ levels in two Antarctic and two temperate water fish species. Comp. Biochem. Physiol. B, Biochem. Mol. Biol. 125, 371-378.

Gillis, T. E. \& Ballantyne, J. S. 1999: Mitochondrial membrane composition of two arctic marine bivalve molluscs, Serripes groelandicus and Mya truncata. Lipids 34, 53-57.

Hawkins, A. J. S. 1991: Protein-turnover-a functional appraisal. Funct. Ecol. 5, 222-233.

Heise, K., Puntarulo, S., Pörtner, H. O. \& Abele D. 2003: Production of reactive oxygen species by isolated mitochondria of the Antarctic bivalve Laternula elliptica (King and Broderip) under heat stress. Comp. Biochem. Physiol. C, Toxicol. Pharmacol. 134, 79-90.

Hofmann, G. E. \& Somero, G. N. 1995: Evidence for protein damage at environmental temperatures: seasonal changes in levels of ubiquitin conjugates and hsp70 in the intertidal mussel Mytilus trossolus. J. Exp. Biol. 198, 1509-1518.

Janssens, B. J., Childress, J. J., Baguet, F. \& Rees, J. F. 2000: Reduced enzymatic antioxidative defence in deep-sea fish. J. Exp. Biol. 203, 3717-3725.

Johnston, I. A., Calvo, J., Guderley, H., Fernandez, D. \& Palmer, L. 1998: Latitudinal variation in the abundance and 
oxidative capacities of muscle mitochondria in perciform fishes. J. Exp. Biol. 201, 1-12.

Koizumi, A., Tsukada, M., Wada, Y., Masuda, H. \& Weindruch, R. 1992: Mitotic activity in mice is suppressed by energy restriction-induced torpor J. Nutr. 122, 1446-1453.

Ku, H. H., Brunk, U. T. \& Sohal, R. S. 1993: Relationship between mitochondrial superoxide and hydrogen peroxide production and longevity of mammalian species. Free Radic. Biol. Med. 15, 621-627.

Marsh, A.G., Maxson, Jr. R. E. \& Manahan, D. T. 2001: High macromolecular synthesis with low metabolic cost in Antarctic sea urchin embryos. Science 291, 1950-1952.

Nolan, C. P. \& Clarke, A. 1993: Growth in the bivalve Yoldiaeightsi at Signy Island, Antarctica determined from internal shell increments and $\mathrm{Ca} 45$ incorporation. Mar. Biol. 117, 243-250.

Orr, W. C. \& Sohal, R. S. 1994: Extension of life span by overexpression of superoxide dismutase and catalase in Drosophila melanogaster. Science 263, 1128-1130.

Peck, L. S. \& Bullough, L. W. 1993: Growth and population structure in the infaunal bivalve Yoldia eightsi in relation to iceberg activity at Signy island, Antarctica. Mar. Biol. $117,235-241$.

Regoli, F., Nigro, M., Bompadre, S. \& Winston, G. 2000: Total oxidant scavenging capacity (TOSC) of microsomal and cytosolic fractions from Antarctic, Arctic and Mediterranean scallops: differentiation between three potent oxidants. Aquat. Toxicol. 49, 13-25.

Regoli, F., Nigro, M., Chiantore, M., Gorbi, S. \& Winston, G. 2000: Total oxidant scavenging capacity of Antarctic, Arctic, and Mediterranean scallops. Ital. J. Zool. 67, 8594.

Regoli, F., Principato, G. B., Bertoli, E., Nigro, M. \& Orlando, E. 1997: Biochemical characterization of the antioxidant system in the scallop Adamussium colbecki, a sentinel organism for monitoring the Antarctic environment. Polar Biol. 17, 251-258.

Regoli, F. \& Winston, G. W. 1999: Quantification of total oxidant scavenging capacity of antioxidants for peroxynitrite, peroxyl radicals and hydroxyl radicals. Toxicol. Appl. Pharmacol. 156, 96-105.

Schulz, A., Rex, M., Harris, N. R. P., Braathern, G. O., Reimer, E., Alfier, R., Kilbane-Dawe, I., Eckermann, S., Allaart, M. Alpers, M., Bojkov, B., Cisneros, J., Claude, H., Cuevas, E., Davies, J., De Backer, H., Dier, H., Dorokhov, V., Fast, H., Godin, S., Johnson, B., Kois, B., Kondo, Y., Kosmidis, E., Kyro, E., Litynska, Z., Mikkelsen, I. S., Molyneux, M. J., Murphy, G., Nagai, T., Nakane, H., O'Connor, F., Parrondo, C., Schmidlin, F. J., Skrivankova, P., Varotsos, C., Vialle, C., Viatte, P., Yushkov, V., Zerefos, C. \& von der Gathen,
P. 2001: Arctic ozone loss in threshold conditions: match observations in 1997/1998 and 1998/1999. J. Geophys. Res. 106(D7), 7495-7503.

Sies, H. 1985: Oxidative stress: introductory remarks. In H. Sies (ed.): Oxidative stress. Pp. 1-8. New York: Academic Press, Harcourt Brace Jovanovich Publishers.

Sohal, R. S., Mockett, R. J. \& Orr, W. C. 2002: Mechanism of aging: an appraisal of the oxidative stress hypothesis. Free Radic. Biol. Med. 33, 575-586.

Stolarski, R., Bojkov, R., Bishop, L., Zerefos, C., Staehelin, J. \& Zawodny, J. 1992: Measured trends in ozone. Science $256,342-349$.

Storch, D., Heilmayer, O., Hardewig, I. \& Pörtner, H. O. 2003: In vitro protein synthesis capacities in a cold stenothermal and a temperate eurythermal pectinid. Comp. Biochem. Physiol. B, Biochem. Mol. Biol. 173, 611-620.

Storch, D. \& Pörtner, H. O. 2003: The protein synthesis machinery operates at the same expense in eurythermal and cold stenothermal pectinids. Physiol. Biochem. Zool. $76,28-40$.

Urban, H. J. \& Mercuri, G. 1998: Population dynamics of the bivalve Laternula elliptica from Potter Cove, King George Island, South Shetland Islands. Antarct. Sci. 10, 153-160.

Viarengo, A., Abele-Oeschger, D. \& Burlando, B. 1998: Effects of low temperature on prooxidant processes and antioxidant defence systems in marine organisms. In H. O. Pörtner \& R. C. Playle (eds.): Cold ocean physiology. Soc. Exp. Biol. Semin. Ser. 66, 212-238.

Viarengo, A., Accomando, R., Roma, G., Benatti, U., Damonte, G. \& Orunesu, M. 1994: Differences in lipid-composition of cell-membranes from Antarctic and Mediterranean scallops. Comp. Biochem. Physiol. B, Biochem. Mol. Biol. 109, 579-584.

Viarengo, A., Canesi, L., Garcia Martinez, P., Peters, L. D. \& Livingstone, D. R. 1995: Pro-oxidant processes and antioxidant defence systems in the tissues of the Antarctic scallop (Adamussium colbecki) compared with the Mediterranean scallop (Pecten jacobeus). Comp. Biochem. Physiol. B, Biochem. Mol. Biol. 111, 119-126.

Weslawski, J. M., Zajaczkowski, M., Kwasniewski, S., Jezierski, J. \& Moskal, W. 1988: Seasonality in an Arctic fjord ecosystem: Hornsund, Spitsbergen. Polar Res. 6, 185-189.

Winston, G. W. \& DiGiulio, R. T. 1991: Prooxidant and antioxidant mechanisms in aquatic organisms. Aquat. Toxicol. 19, 137-191.

Winston, G. W., Regoli, F., Dugas, A. J., Fong, J. H. \& Blanchard, K. A. 1998: A rapid gas chromatographic assay for determining oxyradical scavenging capacity of antioxidants and biological fluids. Free Radic. Biol. Med. 24, 480493. 